\title{
PROJECT-BASED LEARNING DURING ONLINE EDUCATION: CASE OF THE MASTER PROGRAM ON BUSINESS MANAGEMENT IN THE DIGITAL ECONOMY
}

\author{
Maria Tsenzharik \\ Saint Petersburg University, Russian Federation
}

\begin{abstract}
In the article, we will share the experience of implementing PBL at the Master program on Business Management in the Digital Economy held in Saint Petersburg University. Specific conditions for the PBL organization are highlighted. First, digital transformation process is quite difficult to realize in companies, as no clear methodology for its implementation exist yet. Second, pandemic left the only opportunity for online communication, and all usual administration and education processes had to be changed. The experience is structured and presented with recommendations for similar projects.
\end{abstract}

Keywords: business management, digital transformation, distant learning, economic and management education, master programs, project-based learning, university-industry cooperation.

\section{Introduction}

Due to global threats and digital technologies, the internal and external environments permanently change. Very often theory and methodology are not able to catch the changes, especially in the economic and social studies. That is why the practical component has to be included into the learning processes at the master's level. The universities use different forms of convergence between studying and real life, among them are workshops, internship, master classes, simulation games, and project-based learning (PBL).

Project-based learning is a teaching method in which students gain knowledge and skills by working for an extended period of time to investigate and respond to an authentic, engaging, and complex question, problem, or challenge. In this context, Buck Institute for education distinguishes the following PBL objectives (Buck Institute for Education PBLWORKS, n.d.):

- Integration of knowledge and skills from various areas.

- Autonomous learning and solving unstructured problems.

- Teamwork.

- $\quad$ Self-evaluation and self-criticism. 
Tsenzharik, 2021. Project-Based Learning During Online Education: Case of the Master Program on Business Management in the Digital Economy

In management and entrepreneurship, PBL has got an important role, as managerial and entrepreneurial skills are better trained on the base of real projects. Analyses of the latest articles have shown that the following PBL issues are studied: PBL curriculum, students' motivation, wicked problems solving (Kłeczek, Hajdas, Wrona, 2020), project teachers’ self-efficacy (Choi, Lee, Kim, 2019), PBL outcomes and effectiveness measurement (Guo et al., 2020), and other PBL benefits and problems for education process. PBL issues in the context of collaboration between universities and business are almost not concerned.

Studies of cooperation between universities and industry present the independent research area. Most authors consider cooperation between business and the universities in the context of open innovation facilitation, joint research and equipment usage, common funding, and mutual contracts, students' internships etc. For instance, the paper (Ankrah, AL-Tabbaa, 2015) distinguishes some reasons why small and medium companies are interested in cooperation with universities. Mostly the interest is led by external factors such as government stimulation, access to universities facilities and students, economy of resources. Attracting students' teams supervised by the University teachers for business problem solving is not of great attention. Meanwhile, technology growth and integration during the last decade caused significant shifts in the society and economy development. Changes in consumer expectations and behavior, new business processes and business models, new corporate culture and new competencies led to emerging new companies and induced incumbents to transform.

Existing companies need expertise in digital transformation, and academia collective competencies (students' fresh views, energy and mobility coordinated and nourished with professors' theoretical background and practical experience) have a huge potential for business transformation. In this context, realizing digital transformation projects with the help of academia converge to project-based learning objectives, and cooperation has benefits for both.

In turn, pandemic of Covid-19 caused the need in distant communications of different types. It means that all stages of PBL (finding a business partner, discussing the project details, communication between students and a company, controlling and assessing students' work) must be conducted online. (Secundo et al, 2021) paid attention that a small number of studies analyze digital technologies in entrepreneurship education.

Thus, the idea of the article is to show how project-based learning was organized in the sphere of digital transformation under conditions of distant communication. 


\section{Project-based Learning in Saint Petersburg University}

In Saint Petersburg University, we have several programs using projectbased learning. Among them are short program Management of Innovation development and Entrepreneurship supported by the President of Russia (duration 7 months) and Master program on Business management in the Digital Economy (27 months).

The Presidential program curriculum consists of traditional courses on economics, management and innovation activity as well as large block of interactive classes (master classes, soft skills trainings, real and simulation business games, business seminars etc). One of the key parts of the program is development and defense of a business project. When applying for the program, potential students have to present a viable innovation project (oriented to internal or external clients) to be transferred into a solid business plan at the end of the program. During their study, students are involved in different educational areas (marketing, strategy, finance) and must prepare relevant parts of their projects. For instance, after studying marketing block, they develop and defend marketing analysis and marketing strategy of a company. Finally, they present and defend a whole project in front of a special commission including CEO, CFO, CDTO and other top managers from different industries.

Here are examples of some project titles defended during the last years:

- Establishing an innovation company for recycling urban ores

- Creating of small energy generation network for industrial companies

- Implementing unified electronic user pass for sport clubs in Saint Petersburg

- Digital transformation of the open wire lines service and management

So, the program is not just project-based but project-centered. Therefore, there is no difficulties with finding a business partner with a project relevant enough to the program learning aims.

Another program, Business management in the Digital Economy, is more fundamental and at the same time rather new - it started in 2018 and aimed at preparing professionals able to realize business transformation in the digital economy. According to the UNCTAD Report (Building Digital Competencies to Benefit from Frontier Technologies, UNCTAD, 2019), the top managers in the digital economy need the new competences: knowledge of key technologies and digital business models, abilities to establish a digital culture, develop digital transformation strategy, understanding business processes, setting tasks for employees, creating an ecosystem. Besides them, they have to acquire soft skills: business intelligence in decision making, continuous collaboration and interaction with ecosystem participants, ability to work under stress and assist for colleagues. 
Tsenzharik, 2021. Project-Based Learning During Online Education: Case of the Master Program on Business Management in the Digital Economy

Besides economics and management fundamentals, students solve cases, participate in master classes and work in small analytical groups. The program curriculum assumes 4 project seminars each semester, where students work on practical training like problem-based and project-based activities. Therefore, the core idea of the program is to develop the digital transformation strategy on the base of project-based learning, and finding relevant projects is of extremely importance. Moreover, it requires highly motivated top managers which are ready to share detailed information for analysis and open for communication.

The authors (Parrado-Martínez \& Sánchez-Andújar, 2020) notice, that in higher education, project-based learning is usually associated with sciences such as engineering, medicine or psychology, while in the field of economics and finance it is presented purely, mostly for undergraduate students, and has the general idea to improve the following competences: planning and organizing skills; teamwork and cooperation competence, information management ability, oral communicative competence and creativity and innovation competences.

In our program, the project-based learning has to meet the following objectives:

- $\quad$ Show the digital readiness of companies in Russia

- Connect business strategy with the digital strategy

- Demonstrate that digital is a tool, not the aim

- Use business process description as a base for digital transformation

- Make focus on the client-oriented approach

- Apply digital technologies for communication

\section{Digital Transformation Impact on Management}

Having a great experience in business consulting and analytics, we have to note that the most crucial challenges for company management are caused by the processes of digitalization and digital transformation. Very often, terms digitization, digitalization and digital transformation are used as identical while they are significantly different. Thus, digitization is the process of converting analog/physical things (paper documents, microfilm images, photographs, sounds, signals, health records, location data, identity cards, etc.) into a digital format. In its turn, the principal result of digitalization is an integration of digital and physical, connectivity of company functions, and data driven decision making (I-Scoop, n.d.).

As for digital transformation, it is not just about disruption or technology. It concerns value, people, optimization and the capability to rapidly adapt to the changing environment through an intelligent use of technologies and information. Digital allows to better understand business processes and clients demands and 
elaborate effective strategic initiatives (Westerman, 2017). Digital transformation makes impact on three organizational areas: external (customer experience and lifelong client value), internal (business processes, decision making and organizational structure, an organization as a whole (market segments and business functions) (Ismail, Khater, Zaki, 2018).

Being complex, digital transformation processes in companies cause the problems with projects choosing and structuring:

- $\quad$ Fast changes in economic, technological and legal environment require specific approach to company strategizing, management and communication

- Lack of common understanding of digital transformation processes among business community causes mistakes in strategic management

- Insufficient regular management in the most SME leads to very low level of their digital readiness

- Difficulties with finding University instructors with the relevant experience in digital transformation

\section{Project-based Learning during Pandemic}

In 2020, pandemic has led to extreme extension of distant teaching and learning in Russia and over the world. Results of the survey conducted by the International Association of Universities demonstrated that $85 \%$ of the HEI representatives and $85 \%$ of international students answered that presential classes had been replaced by online methodologies, totally or partially; $12 \%$ of the responding HEIs suspending their classes completely, were developing online methodologies and self-study means of learning (IAU, 2020).

The same situation has been observed in Russia: in 2 weeks after lockdown start, over $80 \%$ of universities (450 universities) in Russia went to distant or hybrid form of education. Totally, during several weeks, 95\% students from over the Globe had to start distant or hybrid learning (Ministry of Science and Higher Education of RF, 2020).

Pandemic caused some difficulties in PBL organization. Among them are:

- $\quad$ Finding the relevant company (business partner)

- $\quad$ Conducting interviews with top and middle management

- $\quad$ Structuring the business problems and setting the learning tasks

- Organization of distant communication between students and company employees

- Supervising and controlling the students' activities during the project

- $\quad$ Preparing and presenting the final report.

We had to use distant communication modes such as Zoom, social networks (Facebook, VKontakte, messengers (WhatsApp, Telegram), and email. 
Tsenzharik, 2021. Project-Based Learning During Online Education: Case of the Master Program on Business Management in the Digital Economy

\section{Finding Business Partners for PBL}

Usually, different methods are used for finding a partner. They may be formal or non-formal, using university employees' connections, or official university contacts. Different forms and structures for university and business cooperation are described in (Ankrah, AL-Tabbaa, 2015). Internet browsing also gives us information how universities communicate with business: for example, in Rowan University website (Rowan University, n.d.) one can find a column where potential partners can choose the project area: business and marketing plans, social media strategy, business strategies etc. Information about the company and the project details is submitted electronically via interactive portal. Further project interaction with students, faculty and mentors is also organized distantly with a cloud-based tool EduSourced.com

Our University has a highly centralized structure, and the Economic Faculty has a special department organizing business internships and work placement for students, they have a plenty of agreements with companies. However, usually companies need students for short period tasks, or for conducting routine operations, while we required projects. Moreover, we required digital transformation projects.

The problem is that we have neither special department nor website for projects search. We decided to use social networks as a tool of attracting partners. The choice was made between two popular social networks in Russia: Vkontakte and Facebook. The first is larger in scale, while the second one consolidates older users with higher income (see Table 1) and is positioned as business network. As we were searching for a top positioned manager of a solid company, Facebook was chosen as a communication platform. We joined several groups in Facebook consolidating starters and professionals in digital transformation and made an announcement about our project. Soon after we got two offers from companies and accepted one of them.

Table 1 Users' Characteristics of Social Networks

\begin{tabular}{|l|l|l|l|l|l|}
\hline $\begin{array}{l}\text { Social } \\
\text { network }\end{array}$ & $\begin{array}{l}\text { Number of } \\
\text { users in Russia } \\
\text { (Globe) }\end{array}$ & $\begin{array}{l}\text { Monthly } \\
\text { number of } \\
\text { authors }\end{array}$ & $\begin{array}{l}\text { Monthly } \\
\text { number of } \\
\text { messages }\end{array}$ & $\begin{array}{l}\text { Age } \\
>35\end{array}$ & Users income \\
\hline Vkontakte & $\begin{array}{l}73 \mathrm{mln} \\
(97 \mathrm{mln})\end{array}$ & $28,7 \mathrm{mln}$ & $496,2 \mathrm{mln}$ & $33,4 \%$ & $\begin{array}{l}\text { Average and } \\
\text { above - 71,4\% }\end{array}$ \\
\hline Facebook & $\begin{array}{l}39,7 \mathrm{mln} \\
(2,7 \mathrm{bln})\end{array}$ & $1,6 \mathrm{mln}$ & $56,2 \mathrm{mln}$ & $66,7 \%$ & $\begin{array}{l}\text { Average and } \\
\text { above }-77,7 \%\end{array}$ \\
\hline
\end{tabular}

Sources: (Brand Analytics, n.d.) 


\section{Project Participants Description}

The client: middle machine-building company, 450 employees, involved in digital transformation. They expected students to have a fresh view and to offer effective digital tools for the company management and operations. It means that the top management initially was highly motivated in cooperation with the University and our team.

16 second year Master students. Distribution of their current work sphere: retail -3 , food production - 3, Telecom and ICT - 5, Oil and Gas - 3, construction -2 . Their job in the company: ICT -4 , business analytics -4 , marketing and sales -5 , other -3 .

By the end of the project, they have finished the following courses:

- $\quad$ Strategic Marketing Management

- Management Accounting and Analysis

- Management in the Digital Economy

- Business Economics in the Digital Age

- Investments Evaluation in the Digital Economy

- Business Processes Modeling and Management

- Operations Management and Supply Chain Management

- Leadership and Management

- $\quad$ Strategy of Digital Transformation

- Digital Marketing

- Business Information Analysis

- Data Analysis

- Information Security

- Two project seminars on studying external and internal environment for digital transformation.

Thus, we can conclude that the students have been fundamentally prepared for understanding business processes, analysis and management techniques, economic and financial issues in the digital economy. Moreover, almost all of them were fully employed in large and small companies, so they have their own experience for solving practical tasks in different fields.

Project supervisors. The project was supervised by two persons: associate professor in Business Finance and Management with experience in project management and consulting and financial officer from the large public company with experience in teaching. Both make a common research on digital transformation in companies. They were also motivated and inspired, as they found a business partner and started a project for the Master Program which was also initiated by them. That is why all burden of the project organization has fallen on the supervisors. 
Tsenzharik, 2021. Project-Based Learning During Online Education: Case of the Master Program on Business Management in the Digital Economy

\section{Project Realization and Outcomes}

Usually, educational project realization consists of the following steps: team formation; project briefing; problem restatement and identification; project consultation; demonstration; project report submission; peer assessment; selfreflection; IPBL exit survey (Syafiq et al, 2020)

We structured the project work in the same manner (see Table 2). However, we have to note that the preparatory stage was rather long, due to the reasons highlighted above. First, the company needed recommendations for implementing digital technologies, and the project supervisors had to understand the actual state of operations and management in the company as well as to evaluate its digital maturity. Therefore, we analyzed internal documents, initiated a survey and conducted interviews with managers of all functional departments which were combined into 8 working groups. It made possible to understand company's strengths and weaknesses, threats and opportunities and prepare a plan for students' work.

Table 2 Project Work Stages: Description and Duration

\begin{tabular}{|c|c|c|c|c|}
\hline & Stage & Description & Participants & Duration \\
\hline \multirow[t]{3}{*}{1} & \multirow[t]{3}{*}{$\begin{array}{l}\text { Preparatory } \\
\text { stage }\end{array}$} & $\begin{array}{l}\text { Interview with the company top and } \\
\text { middle managers }\end{array}$ & \multirow[t]{3}{*}{$\begin{array}{l}\text { seminar } \\
\text { supervisors }\end{array}$} & \multirow[t]{3}{*}{3 weeks } \\
\hline & & $\begin{array}{l}\text { Information analysis and problem } \\
\text { formulation }\end{array}$ & & \\
\hline & & Planning the curriculum & & \\
\hline \multirow[t]{3}{*}{2} & \multirow[t]{3}{*}{ Introduction } & Virtual tour at the company & \multirow{3}{*}{$\begin{array}{l}\text { students } \\
\text { seminar } \\
\text { supervisors } \\
\text { other } \\
\text { professors }\end{array}$} & \multirow[t]{3}{*}{1 week } \\
\hline & & $\begin{array}{l}\text { General meeting with the company } \\
\text { tops }\end{array}$ & & \\
\hline & & $\begin{array}{l}\text { Setting business tasks by the } \\
\text { company functional managers }\end{array}$ & & \\
\hline \multirow[t]{2}{*}{3} & \multirow[t]{2}{*}{ Organization } & Forming students' teams & \multirow{2}{*}{$\begin{array}{l}\text { seminar } \\
\text { supervisors }\end{array}$} & \multirow[t]{2}{*}{1 week } \\
\hline & & $\begin{array}{l}\text { Integrating them into the company } \\
\text { functional working groups }\end{array}$ & & \\
\hline \multirow[t]{4}{*}{4} & \multirow[t]{4}{*}{ Realization } & $\begin{array}{l}\text { Getting tasks from seminar } \\
\text { supervisors }\end{array}$ & \multirow{4}{*}{$\begin{array}{l}\text { students } \\
\text { seminar } \\
\text { supervisors }\end{array}$} & \multirow{4}{*}{$\begin{array}{l}4 \text { seminars } \\
\text { during } 8 \\
\text { weeks, } \\
\text { one seminar } \\
\text { in } 2 \text { weeks }\end{array}$} \\
\hline & & $\begin{array}{l}\text { Accumulation and analysis of } \\
\text { information in groups, tasks } \\
\text { fulfillment }\end{array}$ & & \\
\hline & & Preparing presentations & & \\
\hline & & Discussion at seminars & & \\
\hline \multirow[t]{3}{*}{5} & \multirow[t]{3}{*}{ Reporting } & Integrating and summarizing results & \multirow{3}{*}{$\begin{array}{l}\text { students } \\
\text { seminar } \\
\text { supervisors }\end{array}$} & \multirow[t]{3}{*}{2 weeks } \\
\hline & & Preparing the report & & \\
\hline & & $\begin{array}{l}\text { Presenting results for the company } \\
\text { tops }\end{array}$ & & \\
\hline
\end{tabular}


Authors of the article (Kłeczek, Hajdas, Wrona, 2020) have shown that students need the regular supervision during the project, it allows them to better understand aims, analyze relevant information and offer viable solutions. Also, they suggested to divide a complex project into smaller tasks, for better students managing volume and diversity of information. In our group, the project was realized in iterations. Students had to prepare and present the results of their work at each seminar (4 times during the project period). After the class discussion, they were given another assignment for the next 2 weeks. It allowed to apply the outcomes got by other teams for solving problems at another stage. Also, students' assessment was clear, as it was possible to control students' contribution at every stage.

We worked on the project in different ways: analyzing the external environment according to 5 forces by Porter/ 6 forces by Grant, describing internal business processes, determining bottlenecks and potentials, analyzing the best managerial and technological practices, offering technological and organizational solutions.

Usually, to evaluate the work at the end of the course, each group should do an oral presentation of the results with the real documents that they collected. (Parrado-Martínez \& Sánchez-Andújar, 2020). As we described above, students collected documents, conducted interviews and fulfilled special tasks during the period of 8 weeks, and we discussed their work at each seminar.

Finally, students prepared the complex report with recommendations and presented it at the online meeting with the company.

The final report structure was as follows:

1. SWOT-analysis, competitive strategy elaboration and decomposition

2. Marketing: analytics, promotion, organization and tools

3. Production: organization, planning and digitalization

4. Legal affairs: document flows and information system implementation

5. Quality measurement and control organization

6. Recommendations for human resources search and management

7. Procedures for financial analysis, planning and budgeting

8. Suggestions for organizational structure improvement

9. Recommended information systems and communication technologies.

Also, we elaborated an instructors' guide for organization of PBL at the Economic Faculty.

\section{Conclusions and Recommendations}

When realizing digital transformation project in the distant format, it is necessary to pay attention to the sticking points:

1) Insufficient general and strategic management, low company's readiness for digital transformation. The company asked us to offer 
transformation plan and digital tools, however, we had to recommend significant improvements in management and business processes as a necessary stage before digital transformation.

2) Under conditions of digital transformation, a learning project becomes a consulting project. It means that students learn from the company as much as the company learns from them. Therefore, attracting professors for regular consulting of students during the project is needed. Students need assistance of professors competent in different fields (marketing, finance, business process modelling, quality management etc). To solve the problem, some additional professors besides seminar supervisors should be assigned for expertise within the project.

3) When regular communicating with the company employees, students suffered from the delay with the response to their inquiries for necessary information. It is quite obvious, because people in the company are usually busy with their current work. However, to solve the problem, it is sensible to accurately fix the time for response from the company.

4) The curriculum and classes design have to be changed while distant learning. Online meetings with students should be frequent and flexible, sometimes on-demand, with opportunity to clarify all urgent questions. Supervisors should support communication between students and the company

5) During regular studying period, time of one semester (4 months) is rather limited for deep analysis and preparing detailed reports. To solve it, students should have time free of other courses and tasks, or such a complex project should be divided into sub-projects.

\section{References}

Ankrah, S., AL-Tabbaa, O. (2015). Universities-industry collaboration: A systematic review. Scandinavian Journal of Management, Vol. 31, Issue 3, 387-408. https://doi.org/ 10.1016/j.scaman.2015.02.003.

Austin, D., May, J., Andrade, J., Jones, R., (2020). Delivering digital health: The barriers and facilitators to university-industry collaboration. Health Policy and Technology. https://doi.org/10.1016/j.hlpt.2020.10.003.

Brand Analytics. (n.d.). Sistema monitoring in analiza socialinih media i SMI. Retrieved from https://br-analytics.ru/blog/social-media-russia-2020/, https://yandex.ru/turbo/ppc. world/s/articles/auditoriya-shesti-krupneyshih-socsetey-v-rossii-v-2020-goduizuchaem-insayty/

Buck Institute for Education PBLWORKS. (n.d.). What is PBL? Retrieved from https://www.pblworks.org/what-is-pbl) 
Choi, J., Lee, J-H, Kim, B. (2019). How does learner-centered education affect teacher selfefficacy? The case of project-based learning in Korea. Teaching and Teacher Education, Vol. 85, 45-57. https://doi.org/10.1016/j.tate.2019.05.005.

Guo, P., Saab, N., Post, L.S., Admiraal, W. (2020). A review of project-based learning in higher education: Student outcomes and measures. International Journal of Educational Research, Vol. 102. https://doi.org/10.1016/j.ijer.2020.101586.

International Association of Universities (IAU). (2020). COVID-19 impact on Higher Education: Institutional and Students' Perspectives. Retrieved from https://www.iauaiu.net/IMG/pdf/joint_paper_iau_and_esn_-_institutional_and_students_perspectives_ of_covid-19_impact_on_higher_education.pdf

I-Scoop. (n.d.). Digital transformation: online guide to digital business transformation. Retrieved from https://www.i-scoop.eu/digital-transformation/).

Ismail, M. H., Khater, M., Zaki, M. (2017). Digital Business Transformation and Strategy: What Do We Know So Far? University of Cambridge.

Kłeczek, R., Hajdas, M., Wrona, S. (2020). Wicked problems and project-based learning: Value-in-use approach. The international journal of management Education, Vol. 18, issue 1. Retrieved from https://www.sciencedirect.com/science/article/abs/pii/ S1472811719300059?via\%3Dihub

Ministry of Science and Higher Education of RF. (2020). Uroki stress-testa. Vuzy $v$ usloviyah pandemii i posle nee. Analiticheskij doklad. Ministerstvo nauki i Vysshego obrazovaniya $R F$. Retrieved from https://www.hse.ru/data/2020/07/06/1595281277/003_Доклад.pdf

Parrado-Martínez, P., Sánchez-Andújar, S. (2020). Development of competences in postgraduate studies of finance: A project-based learning (PBL) case study. International Review of Economics Education, Vol. 35. https://doi.org/10.1016/j.iree.2020.100192.

Rowan University. (n.d.). Retrieved from https://business.rowan.edu/centers_of_excellence1/ $\mathrm{cel} /$ client-information.html

Secundo, G., Mele, G., Del Vecchio, P., Elia, G., Margherita, A., Ndou, V. (2021). Threat or opportunity? A case study of digital-enabled redesign of entrepreneurship education in the COVID-19 emergency. Technological Forecasting \& Social Change, Vol.166. https://doi.org/10.1016/j.techfore.2020.120565.

Syafiq, M., Ruslan, H., Roil Bilad, M., Hilmi Noh, M., Sufian, S. (2021). Integrated projectbased learning (IPBL) implementation for first year chemical engineering student: DIY hydraulic jack project. Education for chemical engineers, Vol. 35, 54-62. Retrieved from https://proxy.library.spbu.ru:2068/science/journal/17497728

Westerman, G. (2017). Your Company Doesn't Need a Digital Strategy. MIT Sloan Management Review, 25. 